\title{
A Combined VIKOR - Fuzzy AHP Approach to Marketing Strategy Selection
}

\author{
Ali Mohaghar \\ Associate Professor, Faculty of Management, University of Tehran, Tehran, Iran \\ E-mail: amohaghar@ut.ac.ir
}

Mohammad Reza Fathi (Corresponding Author)

Student of master, University of Tehran, Tehran, Iran

Tel: 98-912-751-9265_E-mail: reza.fathi@ut.ac.ir

Mohammad Karimi Zarchi

Student of master, University of Tehran, Tehran, Iran

E-mail:mohammad.karimi@ut.ac.ir

Asie Omidian

Student of master, University of Tehran, Tehran, Iran

E-mail: asiye.omidiyan@ut.ac.ir

Received: May 6, 2011 Accepted: May 24, 2011 doi:10.5296/bms.v3i1.957

\begin{abstract}
This paper presents an integrated fuzzy approach for selecting a marketing strategy. In the integrated approach, fuzzy concepts are used for decision-makers' subjective judgments to reflect the vague nature of the selection process. Fuzzy AHP and VIKOR are included in the integrated approach. Fuzzy AHP is used to determine the fuzzy weights of criteria and sub-criteria because it can effectively determine various criteria's weights in a hierarchical structure. VIKOR aims to rank strategies with respect to the sub-criteria. We apply the
\end{abstract}


integrated approach in real case to demonstrate the application of the proposed method.

Keywords: Fuzzy AHP, Marketing strategy, VIKOR, Multiple criteria decision-making 


\section{Introduction}

Marketing is a critical function that helps corporations in surviving crises. For the past 20 years, greater emphasis has been placed on the role of marketing considerations in the managerial process, underscoring the important role that marketing plays in contributing to a firm's competitive success (Brooksbank et al., 2003). It is widely accepted that the marketing function should enter the managerial process in the early stages (Wind, 1987). To simultaneously pursue increased revenues and profits, decision makers should select one of the diverse ranges of marketing strategies. Various strategic choices imply the need for reasonable implementation and control actions in a diverse set of functional units. In addition, utilizing technology to alter the competitive paradigm suggests that combining computerization with marketing activities offers critical advantages (Stone and Good, 2001). A marketing strategy decision can be classified as a multi-criteria decision-making (MCDM) problem. Marketing strategists should consider a large number of complex factors while evaluating and selecting marketing strategies.

\section{Fuzzy-AHP and VIKOR Methodology}

Fuzzy multiple attribute decision-making (FMADM) methods have been developed owing to the imprecision in assessing the relative importance of attributes and the performance ratings of alternatives with respect to attributes. Imprecision may arise from a variety of reasons: unquantifiable information, incomplete information, unobtainable information and partial ignorance. Conventional MADM methods cannot effectively handle problems with such imprecise information. To resolve this difficulty, fuzzy set theory, first introduced by Zadeh, has been used and is adopted herein. Fuzzy set theory attempts to select, prioritize or rank a finite number of courses of action by evaluating a group of predetermined criteria. Solving this problem thus requires constructing an evaluation procedure to rate and rank, in order of preference, the set of alternatives. We use AHP as a MADM technique with fuzzy logic together. The weights that are gained from fuzzy-AHP calculations are considered and used in VIKOR calculations. Decision making is the process of defining the decision goals, gathering relevant criteria and possible alternatives, evaluating the alternatives for advantages and disadvantages, and selecting the optimal alternative (Hess \& Siciliano, 1996). Hence, first we define the decision goal that here is to select a favorable marketing strategy. Second, it is required to determine and establish some evaluation clusters. Based on marketing resource combinations as drivers of advantage, the previous studies as Barney (1991) and Campbell-Hunt (2000) suggest there are approaches for maximizing advantage above a focus on specific marketing resources and capabilities. For superior performance, enterprises cannot depend upon one element merely. Rather, practitioners need to allocate bundles of marketing resource and capabilities that best fit the unique demands placed on them by their marketing strategy. Therefore, the successful conformation of specific marketing resources and capabilities through marketing strategy develops a complexity that is hard to imitate. strategic marketing resources and capabilities matching the requirements of the marketing strategy create fit for enabling superior performance. The ideal profiles of marketing resources and capabilities for marketing strategies are posited and the superior performance for enterprises always results from marketing resources and capabilities that are in fit with the 
marketing strategy. For marketing strategy alternatives, Porter (1980) introduced a typology of three generic strategies-including overall cost leadership, differentiation, and focus strategies for creating a sustainable position and outperforming competitors in a given industry (Panayides, 2004). With regard to cost strategy, firms might be in a superior position to achieve cost decrement, if they acquire and develop the necessary resources immediately after deciding on a strategy. In the differentiation strategy, the resource-based theory of the firm suggests that similarities in resource requirements among rival companies may increase competition (Barney 1991). In addition, Boyt and Harvey (1997) stated that pursuing differentiation through offering superior customer service would be particularly important, while Grant (1998) pointed out that successful product/service differentiation could be achieved through innovations and improvements across different parts of the value chain. On the basis of Porter's focus strategy, Panayides (2004) investigated the impact of the major beliefs about marketing and suggested that market segmentation is a fundamental precursor to a focused strategy and thus, an important product-market strategy. The benefits of market segmentation could be widespread, ranging from understanding customer needs and delivering customer value to achieving a competitive advantage and improving the organizational performance. According to Porter (1980), Hooley et al. (1992) developed the generic marketing strategy (GMS), including positive growth strategy with high valuable position, growth strategy with alternative objective position, stable growth strategy with general objective position, stable growth strategy with high quality differentiation, and objective defense strategy with low cost. Nevertheless, Kotler (1998) based on the marketing concept proposed; mass marketing strategy, product-variety marketing strategy and target marketing, and developed the market leader strategy, market challenger strategy, marketing follower strategy, and market niche strategy basing on the perspectives of competitive position. McDaniel and Kolari (1987) quoted organization strategy (Miles and Snow, 1978) to demonstrate marketing implementation of defenders, prospectors, analyzers, and reactors. Due to outside and inside surroundings of each corporate, the practitioners would adopt different marketing strategies in the same industry. In respect to marketing strategy, some studies conduct the category and application of marketing mix (Pitt and Kannemeyer, 2000), and some studies apply Porter's generic marketing strategies (Knight, 2000). In addition, the generic marketing strategies could be identified to treat as competitive marketing strategies (Campbell-Hunt, 2000). Hence, the current study adopts Porter's generic strategies of differentiation strategy, cost leadership strategy, and segmentation strategy as marketing strategies for determining the appropriate marketing strategy, based on organization's specific marketing resources and capabilities.Valuable, rare, inimitable and irreplaceable resources, and capabilities make development and maintenance of competitive business advantage possible, when they are used to generate a superior performance ([Kaleka, 2002], [Srivastava et al., 2001], [Barney, 1991] and [Grant, 1991]). Many resources developed for and underpinning marketing activities would be potentially significant advantage-generating resources. A comprehensive survey of Kaleka (2002), Srivastava et al. (2001), and Stewart (1997) reveal that in spite of various marketing resources and firm performance capabilities, not all resources and capabilities can be owned or fully controlled by an organization. Day (1994) divided marketing capabilities into outside-in capabilities, inside-out capabilities, and 


\section{Macrothink}

spanning capabilities. Hooley et al. (1998) proposed four types of marketing assets, including customer based assets, supply chain assets, alliance-based assets, and internal assets. Srivastava et al. (1998) distinguished marketing resources into relational assets and intellectual assets. The typical marketing assets include corporate name and reputation, customer relationship, distribution network, relationship with critical supplier, market knowledge, information system, customer database, legal patent, innovation skills, and optional managerial resources (Olavarietta and Friedmann, 1999). In addition, Luo et al. (2005) also demonstrate the relationship between marketing resources and firm performance; marketing resources include market orientation, entrepreneurial orientation, and innovative orientation. Spillan and Parnell (2006) pointed that marketing resources are: interaction with customer, speed capabilities, systemic analysis, customer-orientation action, coordination, and speedy responsive. And, Ngo and O'Cass (2009) considered that marketing resources and capabilities included marketing basic capabilities, production basic capabilities, and innovation basic capabilities. The most interesting criteria for determining marketing strategies are provided by Hooley et al. (2005) who encapsulated the resources that can gain value in the market place, including market-based resources and marketing support resources, within the term "marketing resources." Thus, marketing resources are those resources that can be immediately deployed in the market-place to create or maintain a competitive advantage, including customer linking capabilities, market innovation capabilities, human resource assets, and reputational assets. On the other hand, the marketing support resources, including managerial capabilities and market orientation, primarily serve primarily to support marketing activities and have an indirect impact on the competitive advantage. The performance-orientated marketing strategy has been driven by marketing resources and capabilities such as human resources and the organization's resources (Edelman et al., 2005). The large number of criteria that should typically be considered in the marketing strategy evaluation process makes it very difficult for marketing strategists. Using the structure of the five aspects as the base and synthesizing the other literature as well as the practical considerations, this study as Lin and $\mathrm{Wu}$ (2008) and Lin et al. (2009) incorporate the marketing resources proposed by Hooley et al. (2005), including managerial capabilities (MC), customer linking capabilities (CLC), market innovation capabilities (MIC), human resource assets (HRA), Capabilities in product distribution (CIPD) and reputational assets (RA).

The managerial capabilities are determined based on the organization's market innovation capabilities and human resource assets. For pursuing customers' satisfaction, practitioners attempt to promote the specific capabilities for product/market innovation. In order to improve the innovation capabilities, practitioners should strengthen the employees' creative abilities for product, service and cooperate with novel managerial process and implementation and customer linking capabilities include the level of customer service, relationships with key target customers, understanding of customers' needs and requirements, creating relationships with new customers, and maintaining and enhancing relationships with existing customers. The customer linking capabilities are concerned with managerial capabilities, market innovation capabilities, human resource assets, capabilities in product distribution and reputation assets. Human resource assets refer to employees' job satisfaction 
and employee retention. The human resource assets are mediated by managerial capabilities, customer linking capabilities, market innovation capabilities, capabilities in product distribution and reputational assets. Capabilities in product distribution refer to the ability of company to access distributing networks and distributing products in different regions. Finally, reputational assets denote the organization's brand name or reputation, and its credibility with customers. The reputational assets are in consequence of the managerial capabilities, customer linking capabilities, market innovation capabilities, and human resource assets. Reputation and brand take time to develop, are intrinsically complex, have difficulty in adding value for customers, help create defensible competitive positions with difficulty of duplication by competitors (Hooley et al., 2005). Finally, it is necessary to apply an fuzzy AHP model and the VIKOR; the fuzzy AHP is used to calculate the weights of elements of evaluation clusters, and the VIKOR is used to rank strategies.

\section{Evaluation Methods}

In this section, some essentials of the fuzzy AHP and the VIKOR are briefly described as follows.

\subsection{Fuzzy AHP}

A good decision-making model needs to tolerate vagueness or ambiguity because fuzziness and vagueness are common characteristics in many decision-making problems (Yu, 2002). Since decision- makers often provide uncertain answers rather than precise values, the transformation of qualitative preferences to point estimates may not be sensible. Conventional AHP that requires the selection of arbitrary values in pairwise comparison may not be sufficient and uncertainty should be considered in some or all pairwise comparison values (Yu, 2002). Since the fuzzy linguistic approach can take the optimism/pessimism rating attitude of decision- makers into account, linguistic values, whose membership functions are usually characterized by triangular fuzzy numbers, are recommended to assess preference ratings instead of conventional numerical equivalence method (Liang \& Wang, 1994). As a result, the fuzzy-AHP should be more appropriate and effective than conventional AHP in real practice where an uncertain pairwise comparison environment exists (Lee, Chen, $\&$ Chang, 2008). There are many fuzzy-AHP methods proposed by various authors (Buckley, 1985; Chang, 1996; Cheng, 1997; Deng, 1999; Leung \& Cao, 2000; Mikhailov, 2004; Van Laarhoven \& Pedrycz, 1983). These methods are systematic approaches to the alternative selection and justification problem by using the concepts of fuzzy set theory and hierarchical structure analysis. Decision-makers usually find that it is more confident to give interval judgments than fixed value judgments. This is because usually he/she is unable to explicit about his/her preferences due to the fuzzy nature of the comparison process. In this study, we prefer Chang (1996) extent analysis method because the steps of this approach are easier than the other fuzzy-AHP approaches (Fuzzy sets and AHP are not detailed here because of being well-known applications). The steps of Chang (1996) extent analysis approach are as follows: Let $\mathrm{X}=\left\{\mathrm{x}_{1}, \mathrm{x}_{2}, \ldots, \mathrm{x}_{\mathrm{n}}\right\}$ be an object set, and $\mathrm{U}=\left\{\mathrm{u}_{1}, \mathrm{u}_{2}, \ldots, \mathrm{u}_{\mathrm{m}}\right\}$ be a goal set. According to the method of Chang (1996) extent analysis, each object is taken and extent analysis for each goal, $\mathrm{g}_{\mathrm{i}}$, is performed, respectively. Therefore, $\mathrm{m}$ extent analysis values for each object can be 
obtained, with the following signs (Dag־ deviren, Yuksel, \& Kurt, in press):

$\widetilde{M}_{g_{i}}^{1}, \widetilde{M}_{g_{i}}^{2}, \ldots, \widetilde{M}_{g_{i}}^{m}, \mathrm{i}=1,2, \ldots, \mathrm{n}$

Where $\widetilde{M}_{g_{i}}^{j}(\mathrm{j}=1,2,3, \ldots, \mathrm{m})$ are all triangular fuzzy numbers. The membership function of the triangular fuzzy number is denoted by $\mathrm{M}_{(\mathrm{x})}$. The steps of the Chang's extent analysis can be summarized as follows:

Step 1: The value of fuzzy synthetic extent with respect to the ith object is defined as:

$$
\mathrm{S}_{\mathrm{i}}=\sum_{j=1}^{m} \widetilde{M}_{g_{i}}^{j} \otimes\left[\sum_{i=1}^{n} \sum_{j=1}^{m} \tilde{M}_{g_{i}}^{j}\right]^{-1}
$$

Where $\otimes$ denotes the extended multiplication of two fuzzy numbers. In order to obtain $\sum_{j=1}^{m} \widetilde{M}_{g_{i}}^{j}$

We perform the addition of $m$ extent analysis values for a particular matrix such that,

$\sum_{j=1}^{m} \widetilde{M}_{g_{i}}^{j}=\left(\sum_{j=1}^{m} l_{j}, \sum_{j=1}^{m} m_{j}, \sum_{j=1}^{m} u_{j}\right)$

and to obtain $\left[\sum_{i=1}^{n} \sum_{j=1}^{m} \widetilde{M}_{g_{i}}^{j}\right]^{-1} \quad$ we perform the fuzzy addition operation of

$\widetilde{M}_{g_{i}}^{j}(\mathrm{j}=1,2, \ldots, \mathrm{m}) \quad$ values such that,

$\sum_{i=1}^{n} \sum_{j=1}^{m} \widetilde{M}_{g_{i}}^{j}=\left(\sum_{i=1}^{n} l_{i}, \sum_{i=1}^{n} m_{i}, \sum_{i=1}^{n} u_{i}\right)$

Then, the inverse of the vector is computed as,

$\left[\sum_{i=1}^{n} \sum_{j=1}^{m} \widetilde{M}_{g_{i}}^{j}\right]^{-1}=\left(\frac{1}{\sum_{i=1}^{n} u_{i}}, \frac{1}{\sum_{i=1}^{n} m_{i}}, \frac{1}{\sum_{i=1}^{n} l_{i}}\right)$

Where $u_{i}, m_{i}, l_{i}>0$

Finally, to obtain the $\mathrm{S}_{\mathrm{j}}$ in Eq. (1), we perform the following multiplication:

$$
\begin{aligned}
& \mathrm{S}_{\mathrm{i}}=\sum_{j=1}^{m} \widetilde{M}_{g_{i}}^{j} \otimes\left[\sum_{i=1}^{n} \sum_{j=1}^{m} \widetilde{M}_{g_{i}}^{j}\right]^{-1} \\
& =\left(\sum_{j=1}^{m} l_{j} \otimes \sum_{i=1}^{n} l_{i}, \sum_{j=1}^{m} m_{j} \otimes \sum_{i=1}^{n} m_{i}, \sum_{j=1}^{m} u_{j} \otimes \sum_{i=1}^{n} u_{i}\right)
\end{aligned}
$$

Step 2: The degree of possibility of $\widetilde{M}_{2}=\left(\mathrm{l}_{2}, \mathrm{~m}_{2}, \mathrm{u}_{2}\right) \geq \widetilde{M}_{1}=\left(\mathrm{l}_{1}, \mathrm{~m}_{1}, \mathrm{u}_{1}\right)$ is defined as 


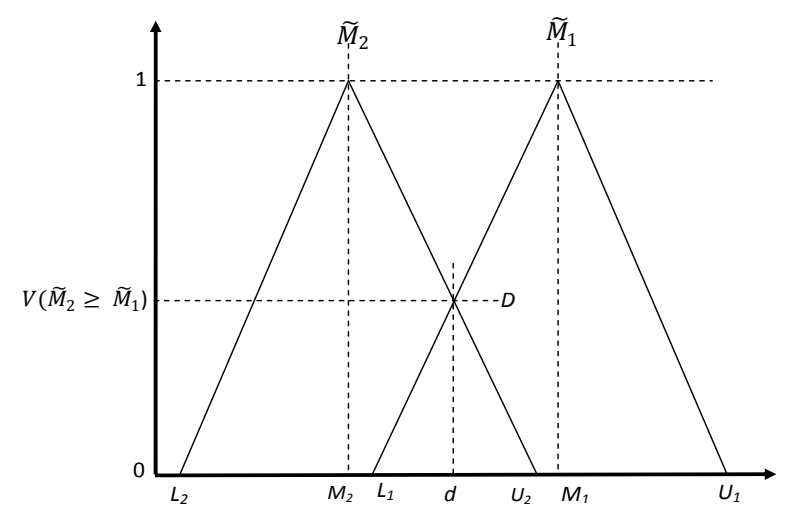

Figure 1.The degree of possibility of $\widetilde{\mathrm{M}}_{1} \geq \widetilde{\mathrm{M}}_{2}$

$\mathrm{V}\left(\widetilde{M}_{2} \geq \widetilde{M}_{1}\right)=\sup \left[\min \left(\widetilde{M}_{1}(\mathrm{x}), \widetilde{M}_{2}(\mathrm{y})\right)\right]$

This can be equivalently expressed as,

$\mathrm{V}\left(\widetilde{M}_{2} \geq \widetilde{M}_{1}\right)=\operatorname{hgt}\left(\widetilde{M}_{1} \cap \widetilde{M}_{2}\right)=\widetilde{M}_{2}(\mathrm{~d})=\left\{\begin{array}{c}1 \quad \text { if } m_{2} \geq m_{1} \\ 0 \quad \text { if } l_{1} \geq u_{2} \\ \frac{l_{1}-u_{2}}{\left(m_{2}-u_{2}\right)-\left(m_{1}-l_{1}\right)}, \text { otherwise }\end{array}\right.$

Fig. 1 illustrates $\mathrm{V}\left(\widetilde{M}_{2} \geq \widetilde{M}_{1}\right)$ for the case $\mathrm{d}$ for the case $\mathrm{M}_{1}<\mathrm{L}_{1}<\mathrm{U}_{2}<\mathrm{M}_{1}$, where $\mathrm{d}$ is the abscissa value corresponding to the highest crossover point $\mathrm{D}$ between $\widetilde{M}_{1}$ and $\widetilde{M}_{2}$, To compare $\widetilde{M}_{1}$ and $\widetilde{M}_{2}$, we need both of the values $\mathrm{V}\left(\widetilde{M}_{1} \geq \widetilde{M}_{2}\right)$ and $\mathrm{V}\left(\widetilde{M}_{2} \geq \widetilde{M}_{1}\right)$.

Step 3: The degree of possibility for a convex fuzzy number to be greater than k convex fuzzy numbers $\mathrm{M}_{\mathrm{i}}(\mathrm{i}=1,2 \ldots \mathrm{K})$ is defined as

$\mathrm{V}\left(\widetilde{M} \geq \widetilde{M}_{1}, \widetilde{M}_{2}, \ldots, \widetilde{M}_{k}\right)=\min \mathrm{V}\left(\widetilde{M} \geq \widetilde{M}_{i}\right), \quad \mathrm{I}=1,2, \ldots, \mathrm{k}$

Step 4: Finally, $\mathrm{W}=\left(\min \mathrm{V}\left(\mathrm{s}_{1} \geq \mathrm{s}_{\mathrm{k}}\right) \min \mathrm{V}\left(\mathrm{s}_{2} \geq \mathrm{s}_{\mathrm{k}}\right), \ldots, \min \mathrm{V}\left(\mathrm{s}_{\mathrm{n}} \geq \mathrm{s}_{\mathrm{k}}\right)\right)^{\mathrm{T}}$, is the weight vector for $\mathrm{k}=1, \ldots, \mathrm{n}$.

\subsection{The VIKOR}

\subsubsection{Introduction to VIKOR}

The VIKOR method is a compromise MADM method, developed by Opricovic .S and Tzeng (Opricovic, 1998; Opricovic, S. and Tzeng, G. H., 2002) started from the form of Lp-metric:

$L_{p i}=\left\{\sum_{j=1}^{n}\left[w_{j}\left(f_{j}^{*}-f_{i j}\right) /\left(f_{j}^{*}-f_{j}^{-}\right)\right]^{p}\right\}^{1 / p} 1 \leq p \leq+\infty ; i=1,2, \ldots I$.

The VIKOR method can provide a maximum "group utility" for the "majority" and a minimum of an individual regret for the "opponent" (Opricovic, 1998; Opricovic, S; Tzeng, G. H., 2002; Serafim Opricovic \& Gwo-Hshiung Tzeng, 2004). 


\section{Macrothink}

\subsubsection{Working Steps of VIKOR Method}

1) Calculate the normalized value

Assuming that there are $\mathrm{m}$ alternatives, and $\mathrm{n}$ attributes. The various $\mathrm{I}$ alternatives are denoted as $\mathrm{x}_{\mathrm{i}}$. For alternative $\mathrm{x}_{\mathrm{j}}$, the rating of the $\mathrm{jth}$ aspect is denoted as $\mathrm{x}_{\mathrm{ij}}$, i.e. $\mathrm{x}_{\mathrm{ij}}$ is the value of $\mathrm{jth}$ attribute. For the process of normalized value, when $\mathrm{x}_{\mathrm{ij}}$ is the original value of the ith option and the jth dimension, the formula is as follows:

$f_{i j}=x_{i j} / \sqrt{\sum_{j=1}^{n} x_{i j}^{2}}, i=1,2, \ldots, m ; j=1,2, \ldots, n$

2) Determine the best and worst values

For all the attribute functions the best value was $f_{j}^{*}$ and the worst value was $f_{j}^{-}$, that is, for attribute $\mathrm{J}=1-\mathrm{n}$, we get formulas (9) and (10)

$f_{j}^{*}=\max f_{i j}, i=1,2, \ldots, m$

$f_{j}^{-}=\min f_{i j}, i=1,2, \ldots, m$

Where $f_{j}^{*}$ the positive ideal solution for the jth criteria is, $f_{j}^{-}$is the negative ideal solution for the jth criteria. If one associates all $f_{j}^{*}$,one will have the optimal combination, which gets the highest scores, the same as $f_{j}^{-}$.

3) Determine the weights of attributes

The weights of attribute should be calculated to express their relative importance.

4) Compute the distance of alternatives to ideal solution

This step is to calculate the distance from each alternative to the positive ideal solution and then get the sum to obtain the final value according to formula (11) and (12).

$S_{i}=\sum_{j=1}^{n} w_{j}\left(f_{j}^{*}-f_{i j}\right) /\left(f_{j}^{*}-f_{j}^{-}\right)$

$R_{i}=\max _{j}\left[w_{j}\left(f_{j}^{*}-f_{i j}\right) /\left(f_{j}^{*}-f_{j}^{-}\right)\right]$

Where $S_{i}$ represents the distance rate of the ith alternative to the positive ideal solution (best combination), $R_{i}$ represents the distance rate of the ith alternative to the negative ideal solution (worst combination). The excellence ranking will be based on $S_{i}$ values and the worst rankings will be based on $R_{i}$ values. In other words, $S_{i}, R_{i}$ indicate $L_{1 i}$ and $L_{* i}$ of $L_{p}$-metric respectively.

5) Calculate the VIKOR values $Q_{i}$ for $\mathrm{i}=1,2, \ldots, \mathrm{m}$, which are defined as

$Q_{i}=v\left[\frac{S_{i}-S^{*}}{S^{-}-S^{*}}\right]+(1-v)\left[\frac{R_{i}-R^{*}}{R^{-}-R^{*}}\right]$ 
Where $S^{-}=\max _{i} S_{i}, S^{*}=\min _{i} S_{i}, R^{-}=\max _{i} R_{i}, R^{*}=\min _{i}, R_{i}$, and $\mathrm{v}$ is the weight of the strategy of "the majority of criteria" (or "the maximum group utility"). $\left[\left(S-S^{*}\right) /\left(S^{-}-S^{*}\right]\right.$ represents the distance rate from the positive ideal solution of the ith alternative's achievements In other words, the majority agrees to use the rate of the ith. $\left[\left(R-R^{*}\right) /\left(R^{-}-R^{*}\right]\right.$ represents the distance rate from the negative ideal solution of the ith alternative; this means the majority disagree with the rate of the ith alternative. Thus, when the $\mathrm{v}$ is larger $(>0.5)$, the index of $Q_{i}$ will tend to majority agreement; when $\mathrm{v}$ is less $(<0.5)$, the index $Q_{i}$ will indicate majority negative attitude; in general, $\mathrm{v}=0.5$, i.e. compromise attitude of evaluation experts.

6) Rank the alternatives by $Q_{i}$ values

According to the $Q_{i}$ values calculated by step (4), we can rank the alternatives and to make-decision.

\section{Empirical Study and Discussions}

This research has been conducted in Yazd Baft Company which produces textile products. The problem is the evaluation of strategies and selection of the most appropriate one. For this reason, first of all, basic six criteria are determined. Secondly, a two step fuzzy-AHP and VIKOR methodology is proposed to realize the evaluation. Via considering these criteria which is including managerial capabilities $\left(\mathrm{C}_{1}\right)$, customer linking capabilities $\left(\mathrm{C}_{2}\right)$, market innovation capabilities $\left(\mathrm{C}_{3}\right)$, human resource assets $\left(\mathrm{C}_{4}\right)$, reputational assets $\left(\mathrm{C}_{5}\right)$, Capabilities in product distribution $\left(\mathrm{C}_{6}\right)$, the weights of three alternatives that include Differentiation strategy $\left(A_{1}\right)$, Cost Leadership strategies $\left(A_{2}\right)$, and Segmentation strategy $\left(A_{3}\right)$ are calculated by using fuzzy-AHP, and these calculated weight values are used as VIKOR inputs. Then, after VIKOR calculations, evaluation of the alternatives and selection of the most appropriate one is realized.

\subsection{Fuzzy AHP}

In fuzzy-AHP, firstly, the criteria and alternatives' importance weights must be compared. For this reason, there must be linguistic terms and their equivalent fuzzy numbers denoting comparison measures. The linguistic comparison terms and their equivalent fuzzy numbers considered in this paper are shown in Table 1.

Table 1. Fuzzy comparison measures

\begin{tabular}{|c|c|}
\hline Linguistic terms & Triangular fuzzy numbers \\
\hline Perfect & $(8,9,10)$ \\
\hline Absolute & $(7,8,9)$ \\
\hline Very good & $(6,7,8)$ \\
\hline Fairly good & $(5,6,7)$ \\
\hline Good & $(4,5,6)$ \\
\hline Preferable & $(3,4,5)$ \\
\hline Not bad & $(2,3,4)$ \\
\hline Weak advantage & $(1,2,3)$ \\
\hline Equal & $(1,1,1)$ \\
\hline
\end{tabular}


Afterwards, for the first step, the comparisons about the criteria and alternatives, and the weight calculation need to be made. Thus, the evaluation of the criteria according to the main goal and the evaluation of the alternatives for these criteria must be realized. Then, after all these evaluation procedure, the weights of the alternatives can be calculated. In the second step, these weights are used to VIKOR calculation for the final evaluation. The comparison matrix for the criteria can be seen from Table 2 .

Table 2. Inter-criteria comparison matrix

\begin{tabular}{|c|c|c|c|c|c|}
\hline Criteria & $\mathrm{C}_{1}$ & $\mathrm{C}_{2}$ & $\mathrm{C}_{3}$ & $\ldots$ & $\mathrm{C}_{6}$ \\
\hline $\mathrm{C}_{1}$ & $(1,1,1)$ & $(5,6,7)$ & $(4,5,6)$ & $\ldots$ & $(1,1,1)$ \\
\hline $\mathrm{C}_{2}$ & $(0.14,0.17,0.20)$ & $(1,1,1)$ & $(1,2,3)$ & $\ldots$ & $(3,4,5)$ \\
\hline $\mathrm{C}_{3}$ & $(0.17,0.20,0.25)$ & $(0.33,0.5,1)$ & $(1,1,1)$ & $\ldots$ & $(0.11,0.13,0.14)$ \\
\hline$\ldots$ & $\ldots$ & $\ldots$ & $\ldots$ & $\ldots$ & $\ldots$ \\
\hline $\mathrm{C}_{6}$ & $(1,1,1)$ & $(0.20,0.25,0.33)$ & $(7,8,9)$ & $\ldots$ & $(1,1,1)$ \\
\hline
\end{tabular}

The weight calculation details using Table 1 are given below. Because of the other calculations are similar for each comparison matrix, these are not given here and can be done simply according the computations below. The value of fuzzy synthetic extent with respect to the ith object $(i=1,2, \ldots, 8)$ is calculated

Thus, the weight vector from Table 2 is calculated as

$w^{t}=(0.307,0.154,0.160,0.235,0.081,0.062)^{\mathrm{T}}$

\subsection{VIKOR}

The weights of the alternatives are calculated by fuzzy AHP up to now, and then these values can be used in VIKOR. So, the VIKOR methodology must be started at the second step. Thus, weighted normalized decision matrix can be prepared. This matrix can be seen from Table 3 .

Table 3. Weighted normalized decision matrix

\begin{tabular}{|c|c|c|c|c|c|c|}
\hline $\mathrm{A}_{\mathrm{i}}-\mathrm{C}_{\mathrm{j}}$ & $\mathrm{C}_{1}$ & $\mathrm{C}_{2}$ & $\mathrm{C}_{3}$ & $\mathrm{C}_{4}$ & $\mathrm{C}_{5}$ & $\mathrm{C}_{6}$ \\
\hline $\mathrm{A}_{1}$ & 0.058 & 0.091 & 0.304 & 0.932 & 0.162 & 0.004 \\
\hline $\mathrm{A}_{2}$ & 0.055 & 0.083 & 0.475 & 0.862 & 0.149 & 0.003 \\
\hline $\mathrm{A}_{3}$ & 0.075 & 0.109 & 0.446 & 0.859 & 0.215 & 0.007 \\
\hline $\mathrm{W}_{\mathrm{j}}$ & 0.307 & 0.154 & 0.160 & 0.235 & 0.081 & 0.062 \\
\hline
\end{tabular}

By following VIKOR procedure steps and calculations, the ranking of strategies are gained. The results and final ranking are shown in Table 4.

Table 4. Final evaluation of the alternatives

\begin{tabular}{|c|l|c|c|c|}
\hline $\mathrm{i}$ & $\mathrm{E}_{\mathrm{i}}=\sum \mathrm{e}_{\mathrm{i}}$ & $\mathrm{F}_{\mathrm{i}}=\operatorname{Max}\left(\mathrm{e}_{\mathrm{i}}\right)$ & $\mathrm{P}_{\mathrm{i}}$ & Ranking \\
\hline $\mathrm{A}_{1}$ & 0.647033 & 0.263414 & 0.534369 & 2 \\
\hline $\mathrm{A}_{2}$ & 0.830809 & 0.306844 & 1 & 3 \\
\hline $\mathrm{A}_{3}$ & 0.262773 & 0.235381 & 0 & 1 \\
\hline $\operatorname{Min}$ & 0.262773 & 0.235381 & 0 & \\
\hline $\operatorname{Max}$ & 0.830809 & 0.306844 & 1 & \\
\hline
\end{tabular}




\section{Conclusions}

For optimal marketing strategy, the current study proposes a marketing strategy decision making process that should also be more operable and practical. An appropriate and simple prioritization method for determining the best marketing strategy would be helpful to firms and marketing strategists. A two step fuzzy-AHP and VIKOR methodology is structured here that VIKOR uses fuzzy-AHP result weights as input weights. Then a real case study is presented to show applicability and performance of the methodology. It can be said that using linguistic variables makes the evaluation process more realistic. Because evaluation is not an exact process and has fuzziness in its body. Here, the usage of fuzzy-AHP weights in VIKOR makes the application more realistic and reliable. The results of this study show that the most important strategy was Segmentation strategy. This study applies integration of VIKOR and fuzzy AHP in marketing field. As a future direction, other decision-making methods such as ELECTRE, GTMA and PC-TOPSIS can be used in this area.

\section{Acknowledgement}

The authors would like to thank the anonymous reviewers and the editor for their insightful comments and suggestions.

\section{References}

Barney, J.B. (1991). Firm resources and sustained competitive advantage. Journal of Management, $17 \quad$ (1), 99-120. doi:10.1177/014920639101700108, http://dx.doi.org/10.1177/014920639101700108

Boyt, T., \&Harvey, M. (1997). Classification of industrial services: a model with strategic implications. Industrial Marketing Management, 26, 291-300. doi:10.1016/S0019-8501(96)00111-3, http://dx.doi.org/ S0019-8501(96)00111-3

Brooksbank, R., Kirby, D., Tompson, G., \& Taylor, D. (2003). Marketing as a determinant of long-run competitive success in medium-sized UK manufacturing firms, Small Business Economics, 20, 259-272. doi:10.1023/A:1022885132039, http://dx.doi.org/10.1023/A:1022885132039

Buckley, J. J. (1985). Fuzzy hierarchical analysis. Fuzzy Sets and Systems, 17(3), 233-247. doi:10.1016/0165-0114(85)90090-9, http://dx.doi.org/10.1016/0165-0114(85)90090-9

Campbell-Hunt, C. (2000). What have we learned about generic competitive strategy: a Meta analysis. Strategic Management Journal, $21 \quad$ (2), 127-154. doi:10.1002/(SICI)1097-0266(200002)21:2<127::AID-SMJ75>3.0.CO;2-1, http://dx.doi.org/10.1002/(SICI)1097-0266(200002)21:2<127::AID-SMJ75>3.0.CO;2-1

Chang, D. Y. (1996). Applications of the extent analysis method on fuzzy AHP. European Journal of Operational Research, 95(3), 649-655. doi:10.1016/0377-2217(95)00300-2, http://dx.doi.org/10.1016/0377-2217(95)00300-2

Cheng, C. H. (1997). Evaluating naval tactical missile systems by fuzzy AHP based on the grade value of membership function. European Journal of Operational Research, 96(2), 
$343-350$.

http://dx.doi.org/10.1016/S0377-2217(96)00026-4

Dag ־deviren, M., Yüksel,_I., \& Kurt, M. (in press). A fuzzy analytic network process.(ANP) model to identify faulty behavior risk (FBR) in work system. Safety Science.

Day, G.S. (1994). The capabilities of market-driven organizations. Journal of Marketing, 58 (4), 37-52. doi:10.2307/1251915, http://dx.doi.org/10.2307/1251915

Deng, H. (1999). Multicriteria analysis with fuzzy pairwise comparison. International Journal of Approximate Reasoning, 21(3), 215-231. doi:10.1016/S0888-613X(99)00025-0, http://dx.doi.org/10.1016/S0888-613X(99)00025-0

Edelman, L.F., Brush, C.G., \& Manolova, T. (2005). Co-alignment in the resource performance relationship: strategy as mediator. Journal of Business Venturing, 20 (3), 359-383.

Grant, R.M. (1991). The resource-based theory of competitive advantage: implications for strategy. California Management Review, 33 (3), 114-135.

Grant, R.M. (1998). Contemporary Strategy Analysis: Concepts, Techniques, Applications. 3rd ed. Blackwell business, Maiden, MA.

Hess, P., \& Siciliano, J. (1996). Management: Responsibility for performance, New York: McGraw-Hill.

Hooley, G.J., Greenley, G.E., Cadogan, J.W., \& Fahy, J. (2005). The performance impact of marketing resources. Journal of Business Research, 58 (1), 18-27.

Hooley, G.J., Lynch, J.E., \& Jobber, D. (1992). Generic marketing strategies. International Journal of Research in Marketing, 9 (1), 75-89.

Hooley, G.J., Saunders, J.A., \& Piercy, N.P. (1998). Marketing Strategy and Competitive Positioning 2nd ed. Prentice Hall International, Hemel Hempstead.

Hughes, P., \& Morgan, R.E. (2008). Fitting strategic resources with product-market strategy: performance implications. Journal of Business Research, 61 (4), 323-331. doi:10.1016/j.jbusres.2007.06.023, http://dx.doi.org/10.1016/j.jbusres.2007.06.023

Kaleka, A. (2002). Resources and capabilities driving competitive advantage in export markets: guidelines for industrial exporters. Industrial Marketing Management, 31, 273-283. doi:10.1016/S0019-8501(00)00148-6, http://dx.doi.org/10.1016/S0019-8501(00)00148-6

Lee, A. H. I., Chen, W.-C., \& Chang, C.-J. (2008). A fuzzy AHP and BSC approach for evaluating performance of IT department in the manufacturing industry in Taiwan. Expert Systems with Applications, 34(1), 96-107. doi:10.1016/j.eswa.2006.08.022, http://dx.doi.org/10.1016/j.eswa.2006.08.022

Leung, L. C., \& Cao, D. (2000). On consistency and ranking of alternatives in fuzzy AHP. European Journal of Operational Research, 124(1), 102-113. 
doi:10.1016/S0377-2217(99)00118-6, http://dx.doi.org/10.1016/S0377-2217(99)00118-6

Liang, G. S., \& Wang, M. J. (1994). Personnel selection using fuzzy MCDM algorithm.European Journal of Operational Research, 78, 22-33. doi:10.1016/0377-2217(94)90119-8, http://dx.doi.org/10.1016/0377-2217(94)90119-8

Lin, C.T., \& Wu, C.S. (2008). Selecting marketing strategy for private hotels in Taiwan using the analytic hierarchy process. The Service Industries Journal, 28 (8), 1077-1091. doi:10.1080/02642060802187991, http://dx.doi.org/10.1080/02642060802187991

Lin, C.T., Lee, C., \& Wu, C.S. (2009). Optimizing a marketing expert decision process for the private hotel. Expert Systems with Applications, 36 (3), 5613-5619. doi:10.1016/j.eswa.2008.06.113, http://dx.doi.org/10.1016/j.eswa.2008.06.113

Luo, X., Sivakumar, K., \& Liu, S.S. (2005). Globalization, marketing resources, and performance: evidence from China. Journal of the Academy of Marketing Science, 33 (1), 50-65. doi:10.1177/0092070304265050, http://dx.doi.org/10.1177/0092070304265050

McDaniel, S.W., \& Kolari, J. (1987). Marketing strategy implications of the miles and snow strategic typology. Journal of Marketing, 51 (4), 19-30. doi:10.2307/1251245, http://dx.doi.org/10.2307/1251245

Mikhailov, L. (2004). A fuzzy approach to deriving priorities from interval pairwise comparison judgments. European Journal of Operational Research, 159(3), 687-704. doi:10.1016/S0377-2217(03)00432-6, http://dx.doi.org/10.1016/S0377-2217(03)00432-6

Miles, R., \& Snow, C., (1978). Organizational Strategy, Structure, and Process. McGraw Hill, New York.

Ngo, L.V., \& O’Cass, A., (2009). Creating value offerings via operant resource-based capabilities. Industrial Marketing Management, $38 \quad$ (1), 45-59. doi:10.1016/j.indmarman.2007.11.002, http://dx.doi.org/10.1016/j.indmarman.2007.11.002

Olavarrieta, S., \& Friedmann, R. (1999). Market oriented culture, knowledge-related resources, reputational assets and superior performance: a conceptual framework. Journal of Strategic Marketing, 7 (4), 215-228. doi:10.1080/096525499346332, http://dx.doi.org/10.1080/096525499346332

Opricovic, S., \& Tzeng. G.H. (2004). Compromise solution by MCDM methods: A comparative analysis of VIKOR and TOPSIS, European Journal of Operational Research, 156, 445-455. doi:10.1016/S0377-2217(03)00020-1, http://dx.doi.org/10.1016/S0377-2217(03)00020-1

Opricovic, S., \& Tzeng, G. H. (2002). Multicriteria planning of post earthquake sustainable reconstruction, Computer-Aided Civil and Infrastructure Engineering, 17, 211-220. doi:10.1111/1467-8667.00269, http://dx.doi.org/10.1111/1467-8667.00269

Opricovic. (1998). "Multi-criteria optimization of civil engineering systems, "Faculty of Civil Engineering, Belgrade. 


\section{Macrothink}

Business Management and Strategy

ISSN 2157-6068 2012, Vol. 3, No. 1

Panayides, M. (2004). Logistics service providers: an empirical study of marketing strategies and company performance. International Journal of Logistics: Research \& Applications, 7 (1), 1-15.

Pitt, L.F., \& Kannemeyer, R., (2000). The role of adaptation in micro enterprise development: a marketing perspective. Journal of Developmental Entrepreneurship, 5 (2), 137-155.

Porter, M.E. (1980). Competitive Strategy: Techniques for Analyzing Industries and Competitors. The Free Press, New York.

Spillan, J., \& Parnell, J., (2006). Marketing resources and firm performance among SMEs. European Management Journal, 24 (2-3), 236-245. doi:10.1016/j.emj.2006.03.013, http://dx.doi.org/10.1016/j.emj.2006.03.013

Srivastava, R.K., Christensen, H.K., Fahey, L., (1998). Market-based assets and shareholder value: a framework for analysis. Journal of Marketing, 62 (1), 2-18. doi:10.2307/1251799, http://dx.doi.org/10.2307/1251799

Srivastava, R.K., Fahey, L., \& Christensen, H.K. (2001). The resource-based view and marketing: the role of market-based assets in gaining competitive advantage. Journal of Management, (27), 777-802. doi:10.1177/014920630102700610, http://dx.doi.org/10.1177/014920630102700610

Stewart, T.A. (1997). Intellectual Capital: The New Wealth of Organizations. Doubleday, New York.

Stone, R.W., \& Good, D.J. (2001). The assimilation of computer-aided marketing activities. Information and Management, (38), 437-447. doi:10.1016/S0378-7206(00)00080-X, http://dx.doi.org/10.1016/S0378-7206(00)00080-X

Van Laarhoven, P. J. M., \& Pedrycz, W. (1983). A fuzzy extension of Saaty's priority theory. Fuzzy Sets and Systems, 11(1-3), 229-241.

Wind, Y. (1987). An analytic hierarchy process based approach to the design and evaluation of a marketing driven business and corporate strategy. Mathematical Modeling, 9 (3-5), 285-291.

doi:10.1016/0270-0255(87)90484-2,

http://dx.doi.org/10.1016/0270-0255(87)90484-2

Yu, C. S. (2002). A GP-AHP method for solving group decision-making fuzzy AHP problems. Computers and Operations Research, 29, 1969-2001. doi:10.1016/S0305-0548(01)00068-5, http://dx.doi.org/10.1016/S0305-0548(01)00068-5 